\title{
Partner Violence in Muslim Marriages: Tips for Therapists in the US
}

\author{
Esra Nihan Bridge ${ }^{1}$ [C] \\ Kadıköy Counseling and Research Center
}

\author{
Nesrin Duman ${ }^{2}$ (]) \\ Bartın University
}

\begin{abstract}
Partner violence in Muslim marriages is one of the most challenging subjects in the therapy setting for both therapists and Muslim clients. Due to the lack of studies and the negative reputation of Muslim families' in Western culture, many therapists may carry stereotypes about partner violence in Muslim societies. Moreover, as a result of these same reasons, many Muslim clients might be hesitant to seek help or share their negative experiences. In family therapy, therapists would benefit from knowing what Muslim marriages are like and from learning to respect their clients' cultural values. Understanding Muslim families better can be valuable in the therapy setting for many Muslim clients by helping therapists recognize abuse and enabling clients to seek help for partner violence. The current study aims to guide therapists in understanding marriages, cultural values, and partner violence in terms of Muslim marriages; to prepare them for challenges in therapy; and also to encourage future studies focused on preventing and combatting intimate partner violence.
\end{abstract}

\section{Keywords:}

Muslim marriages $\bullet$ Intimate partner violence $\bullet$ Couples $\bullet$ Violence $\bullet$ Therapist

Müslüman Evliliklerde Partner Şiddeti: ABD’deki Terapistler İçin Öneriler

$$
\text { Özet }
$$

Müslüman evliliklerde partner şiddeti, hem terapistler hem de Müslüman danışanlar için terapi ortamındaki en zorlu konulardan biridir. Çalışmaların yetersizliği ve Müslüman ailelerin Batı kültüründeki olumsuz itibarı nedeniyle, pek çok terapist Müslüman toplumlarda partner şiddeti ile ilgili önyargılar taşıyabilmektedir. Ayrıca, bu benzer nedenlerin bir sonucu olarak, birçok Müslüman danışan yardım istemede veya olumsuz deneyimlerini paylaşmada tereddüt yaşayabilir. Aile terapisinde, Müslüman evliliklerin nasıl olduğunu bilmek ve danışanların kültürel değerlerini ögrenmek terapistlere fayda sağlayacaktır. Müslüman aileleri terapi ortamında daha iyi anlamak, birçok Müslüman danışana yönelik terapilerde terapistlerin şiddeti tanımalarına yardımcı olmada ve danışanların partner şiddeti için yardım aramalarını sağlamada değerli olabilir. Bu çalışma, terapistlere Müslüman evliliklerini, kültürel değerlerini ve partner şiddetini anlamada rehberlik etmeyi; onları terapideki zorluklara hazırlamayı ve ayrıca eşe/partnere yönelik şiddeti önleme ve bunlarla mücadeleye odaklanmış gelecekteki çalışmaları teşvik etmeyi amaçlamaktadır.

Anahtar Kelimeler:

Müslüman evlilikler • Yakın partner șiddeti • Çiftler, Şiddet • Terapist

\footnotetext{
1 Istanbul Kadıköy Counseling and Research Center, Istanbul-Turkey. E-mail: esranihanbridge@gmail.com

2 Correspondence to: Nesrin Duman. Bartin University Psychology Department Kutlubey Campus, Bartın-Turkey. E-mail: nesrinduman@bartin.edu.tr

Citation: Bridge, E. N., \& Duman, N. (2019). Partner violence in Muslim marriages: Tips for therapists in the US. Spiritual Psychology and Counseling 4, 57-66. http://dx.doi.org/10.12738/spc.2019.4.1.0055
} 
Understanding cultural diversity and assessing religion's impact on families have increasingly received attention from many therapists and researchers in the field of family therapy (Daneshpour, 1998, 2016). Even though a large Muslim population exists in the US, the majority consists of African-Americans, Asians, and Arabs (Abugideiri, 2010) with the religion of Islam still being one of the most unfamiliar and misjudged religions in the world (Mohamad, 1996). Daneshpour (1998) stated Western thinking to have many negative opinions related to Islam, such as the religion being oppressive to women and many Muslim men being aggressive or terrorists (Daneshpour, 1998, 2016). One can predict that many therapists also might lack information or even carry negative assumptions about the religion.

Daneshpour (1998) believes that this negative reputation causes Muslim people in the USA some reluctance in seeking therapy. The fears of being judged and of being viewed as irrational may cause many Muslims to resist seeking therapy, even in serious situations (Daneshpour, 1998, 2016). In the field of family therapy, having therapists know what Muslim marriages are like and learning to respect clients' cultural/religious values is very important for clients being able to feel understood and respected in a therapy setting. For Muslim clients as well as the therapists, partner violence in Muslim marriages appears as one of the most difficult topics. Partner violence includes physical-sexual-emotional violence, stalking, and psychological aggression (including coercive acts) by a current or former intimate partner ("Intimate partner", 2018). When Muslim families in the USA encounter partner violence, many of them may be reluctant to seek help or talk about their negative experiences in a therapy setting. Moreover, in some situations, therapists might overreact about the power dynamics in couple relations or be confused about the indicators of partner violence in Muslim marriages. For this reason, understanding the values of Muslim families can be invaluable for therapists and many Muslim clients for recognizing and assisting with partner violence. The purpose of this paper is to address partner violence for Muslims in family therapy. It aims to guide therapists in understanding marriage, cultural values and partner violence in Muslim marriages, in preparing them for challenges in therapy, and also in encouraging future studies focused on preventing and combatting intimate partner violence.

\section{Muslim Marriages and Cultural Values}

To begin with, providing some information about Muslim marriages and family cultural values is crucial for comprehending this culture. Even though the term Muslim marriage is used to describe the general characteristics of the community, this term seems to minimize the differences between customs and tradition (Robinson, 2010). While marriage in Muslim culture may have some similarities with marriages in other cultures, is also has obvious differences. Primarily, many Muslim people also 
desire to have a religious ceremony apart from the official marriage to be counted as married in their religion (Daneshpour, 1998, 2016). A Muslim marriage ceremony takes place with a religious guide (Ayyub, 2000) and involves certain prayers. Many times this religious ceremony will be held after a short period of time after the couple has started dating, as opposed to the long engagements in USA culture. One of the motives for Muslim couples to get married early is their desire to receive Allah's blessing before they become involved in a sexual relationship.

The most significant differences in Muslim marriages appear in gender roles. For example, according to Abugideiri (2010), many Muslim women might presume that one of the ways to worship God is by being the best wife to their husbands. On the other hand, many traditional Muslim men might desire to have control over their family instead of sharing power (Ayyub, 2000). Also, many traditional Muslim women can surmise that their husbands' responsibility is to lead the family according to Muslim guidelines (Abugideiri, 2010). They may be more willing to follow their husbands' rules. Many Muslim families usually adopt a patriarchal system; therefore, traditional Muslim men might maintain authority over making decisions (Ayyub, 2000). This authority can cause the Muslim women to think that asking their husbands' permission is mandatory when she wants to do something, such as going out or meeting up with friends. Consequently, many married Muslim women find obeying their husbands to be appropriate when their husbands do not approve of something, thus giving up something they desire.

Even if they live within USA culture, many Muslim women still might hold some traditional beliefs about problems in marriage (Abugideiri, 2010). Some Muslim women believe extremely that they are responsible for failures in the marriage; therefore, they experience shame during marital conflicts (Abugideiri, 2010). Daneshpour (1998) stated that many Muslim families also see themselves as the root of any problems. For instance, parents may consider a child's behavioral problems to be due to their lack of responsiveness to the child's needs (Daneshpour, 1998).

In addition to seeing personal and marital problems as a failure, discussing them with family or outsiders is another challenging topic for Muslim couples. Sharing problems in their marriage and seeking support from others for marital problems can bring shame to Muslim couples (Daneshpour, 1998). These women may also believe that, if they talk about their private problems, the community might ostracize them for sharing details of their marriage and for not respecting their husband (Abugideiri, 2010). One may predict that with this belief, intimate partner violence is able to remain undiscovered for long periods of time. Aside from seeking support through resources, Muslim women asking for help from their parents for their marital problems may also be dishonorable (Abugideiri, 2010). Al-Krenawi and Graham (2005) mentioned the 
extended family's power and influence over the family. In some situations, extended families can exacerbate existing problem by blaming the mother for her parenting skills or criticizing her for not managing the marriage well. Especially in serious marital problems, many women may be hesitant to go back to their parents' house, or her parents may not even accept her back home.

In terms of divorce, even though Islam views divorce as a very unpleasant and bitter event, Muslim law allows a couple to divorce (Daneshpour, 1998). Unlike legal divorce, the Muslim way of divorcing can only be done verbally (Isgandarova, 2018). In talaq (repudiation, divorce), the husband has a right to dissolve the marriage by simply announcing to his wife that he repudiates her. However, the main point is usually how the Muslim families react to divorce. As previously stated, many Muslim women might consider divorce as a failure, and they find it shameful to go back to their parents' house. Also, the extended family may oppose their daughter's divorce and force her to remain married and be patient. Being divorced can be considered especially reprehensible for women. Moreover, a custody battle may arise; child custody can cause serious problems for the couple, especially when they attempt to remarry. In addition, Muslim children with divorced parents who grow up with only one parent and are removed from the other it can be challenging and considered reprehensible. This might also cause the child/children to be ostracized in the community (Abugideiri, 2010). As a consequence, many Muslim couples may desire to begrudgingly stay married to keep the family together.

\section{Partner Violence in Muslim Marriages}

When the issue is of violence in the domestic setting, anyone in the Muslim family can undeniably become the victim. Researchers have emphasized violence in Muslim marriages to be unrelated to any race, ethnicity, or socio-economic level (Faizi, 2011); the perpetrators and victims of violence can also come from any Islamic sect (Khan, 2006). The current literature has demonstrated partner violence in Muslim marriages to appear as physical, sexual, or emotional violence (Faizi, 2011) and may also include spiritual, verbal, and financial abuse (Isgandarova, 2018). Khan (2006) reported the research on Muslim families to have illustrated $47 \%$ of the Muslim community to have suffered from some type of domestic violence, and $12 \%$ of the Muslim community in the US to have experienced physical violence in the families. The literature has a lack of studies, particularly on partner violence in Muslim marriages.

According to Ayyub's (2000) study with South Asian Muslim families, those who had experienced partner violence indicated the majority of cases to be about power sharing and control. While fewer percentages of cases involved alcohol or substance abuse, nearly $20 \%$ of clients said it involved another woman (Ayyub, 2000). Surveys 
have indicated women and children in Muslim communities to have experienced tremendous risks of violence (Abugideiri, 2010). Isgandarova (2017) conducted a study to explore domestic violence against pregnant women and interviewed seven Azerbaijani Muslim women. That study revealed the baby's gender to also play a crucial role in violence against pregnant women. While many families prefer boys over girls, discovering that a baby is female may lead to emotional and physical violence. That study's participants stated that putting emotional pressure on women to have a boy and/or threatening them with divorce are common ways to emotionally abuse pregnant women. Furthermore, some husbands might force women to have an abortion if the baby's gender is learned to be female, even though sex-selective abortion in Islam is prohibited. The study demonstrated that, if a family is going through financial struggles, women are usually blamed for getting pregnant, which will cause more financial problems (Isgandarova, 2017).

Firstly, mention how the religion of Islam views violence in marriage is imperative. Khan (2006) stated that Islam, like many other religions, aims to promote harmony and peace everywhere, including in marriage. Islam emphasizes being patient and practicing perseverance in overcoming challenges; however, this cannot be interpreted as the religion silently enduring violence (Abugideiri, 2010). Lack of knowledge about Islam usually leads to the idea that Islam tolerates violence towards the wife (Ibrahim \& Abdalla, 2011); however, Islam certainly does not promote domestic violence (Khan, 2006), as violence in the marriage being unacceptable in Islam is very wellknown by most Muslims (Abugideiri, 2010). Furthermore, many Muslim women are quite certain that God abhors oppression and injustice (Abugideiri, 2010). Ibrahim and Abdalla (2011) stated the reason why partner violence is associated with Muslim marriages to be an attribution to verse 4:34 in the Qur'an. While this verse simply explains a husband's responsibilities toward the wife, reading that specific verse out of context has misled many to think that Islam allows partner violence. Even though many Muslim women know the Qur'an does not legitimize violence towards spouses (Ibrahim \& Abdalla, 2011) and oppression and violence to be unacceptable, they can experience moments of confusion and doubt in violent situations (Abugideiri, 2010).

Because being a good wife and being patient during challenges are promoted in the religion, this belief can affect Muslim women's behaviors toward violence. Isgandarova (2017) stated that not seeking support and not reporting violence to the police is fairly common among Muslim women. Due to their desire to keep the family together, many Muslim women sacrifice themselves and tolerate domestic violence. Noting that Muslim people are not more resilient to domestic violence than other populations is imperative (Abugideiri, 2010). However, many Muslim women remain in an abusive relationship for a long time, and acknowledging the reasons is crucial. Recognizing women's role in keeping the family together in Muslim culture is imperative. Faizi (2011) reported 
the most common reasons for Muslim women staying in abusive relationships to be financial dependency, unwillingness to break the family apart, hope that the violence will end, and/or social pressure, which is not at all different from the reasons for nonMuslim women who stay in abusive relationships.

The literature has demonstrated that marital conflicts can appear during acculturation processes due to adjusting to the differences in new societies and the major changes in daily, family, and social life (Al-Krenawi \&Graham, 2005). Ammar, Couture-Carron, Alvi, and San Antonio (2014) researched domestic violence with female Muslim immigrants and compared their results to female non-Muslim immigrants, finding out that $23 \%$ of female Muslim immigrants and $27 \%$ of female non-Muslim immigrants stated still experiencing violence from an intimate partner and the main reasons for them remaining in the relationship to be financial reasons, lack of social support, fear of the perpetrator, cultural and religious beliefs, and/or immigration-related issues (Ammar et al. 2014). This study also indicated in its comparison of both Muslim and non-Muslim immigrant women, nearly $35 \%$ of the Muslim women reported cultural and religious beliefs and fear of the community's negative reactions toward divorce to be critical factors for their staying in the relationship (Ammar et al. 2014).

Not only are cultural and religious values crucial for understanding intimate partner violence, but also the view of Muslim community toward partner violence. Firstly, some Muslims can find being violent or being faced with violence acceptable under certain circumstances. Abugideiri (2010) stated that some Muslims might approve or accept wife beating when it comes to disobedience, infidelity, or insulting behavior towards the husband because Islam sees the husband as the protector and maintainer of his wife and gives him the responsibility of heading the family. This approach encourages the wife to obey her husband. As stated before, if a Muslim woman does not receive her husband's approval before acting or does things which her husband opposes, she can be considered disobedient and the Muslim community can view the violence as acceptable. According to Abugideiri (2010), many Muslim women can justify experiencing and accepting violence for having had an affair. Furthermore, some Muslim men may increase the level of violence, even killing their wives as a result of an affair (Abugideiri, 2010).

Furthermore, other risk factors are powerful in understanding intimate partner violence in Muslim marriages. Isgandarova (2017) emphasized that one of the reasons women become vulnerable to partner violence is early-age marriage. Similar to the literature, poverty, alcohol, and substance abuse are also considered risk factors that contribute to domestic violence (Isgandarova, 2017). Abugideiri (2010) stated that many Muslim women who have been in abusive relationships realized during the therapy sessions that their parents had been in a similar type of relationship and 
that their father had been abusive to their mother. This information demonstrates that witnessing violence in one's parents' relationships can be considered a risk factor for Muslim women in their tolerance of abuse and refusal to leave an abusive relationship with their husband. Moreover, one can assume that witnessing familial violence can be a risk factor for Muslim men's violence in their marital relationship. For this reason, intimate partner violence in Muslim families should be recognized as being able to also resemble partner violence in other cultures and as being unexplainable through strictly religious or cultural values.

\section{Discussion and Conclusion}

The prevalence of partner violence in Muslim marriages is not fully known due to the limited studies. Moreover and as stated before, domestic violence in Muslim families is usually concealed for several reasons (Khan, 2006). The most critical cause intriguing the mental health field is Muslim families' hesitance in seeking help. While some clients might find talking about their private life acceptable, others might consider this as a betrayal to the family. Sharing problems in their marriage and seeking support from others for marital problems can also bring shame to Muslim couples (Daneshpour, 1998, 2016). In addition, Muslim women might be reluctant to go to therapy due to her belief that a non-Muslim therapist will not understand her or that she will be underestimated or judged. In therapy settings, a non- Muslim therapist can find connecting with Muslim clients, staying unbiased, fully understanding their experiences, and properly recognizing violence in their relationships to be challenging. While two of the main reasons are the lack of studies and therapists' lack of knowledge about what Muslim marriages are like, another reason might relate to the biases against Muslim people and a negative reputation. For this reason, becoming a culturally competent therapist and understanding the values of Muslim families can be beneficial for many Muslim clients in several areas, particularly in seeking help for partner violence.

In two case studies of Arab Muslim Palestinian couples, Al-Krenawi and Graham (2005) emphasized the challenges of working with Muslim couples in therapy. They reported that the couple usually prefers talking about difficult issues in their individual sessions; the women may not mention violence until having an individual session. Therefore, having individual sessions with both partners could be beneficial for therapists. Also in couple's therapy, Muslim men may try to control the therapy session and compete with the therapist to gain authority (Al-Krenawi \& Graham, 2005). In this situation, until a therapeutic alliance occurs, understanding and respecting Muslim men's desire to be powerful may assist the therapist. Al-Krenawi and Graham (2005) stated that, in some situations, the therapist's gender might create a conflict for the Muslim couple. For instance, some Muslim women might believe a male therapist will take her husband's side and, for this reason, might prefer a female 
therapist. Additionally, Muslim women in couple's therapy might stay more passive and rely on the therapist to explain to their husbands their negative feelings, rather than talk about them (Al-Krenawi \& Graham, 2005).

Therapists need to stay present and neutral and hear the client's story and perceptions of their marriage in the therapy setting without judging. Religion is indispensable for most Muslims in their daily life, and not respecting their values might cause them to limit their interactions with others (Robinson, 2010). Because unfamiliar approaches and suggestions are usually not internalized by clients, therapists should take into consideration the importance of religion in the roles of marriage, divorce, and gender for Muslim clients and should adopt an approach compatible with Muslim values (Daneshpour, 1998, 2016) Al-Krenawi and Graham (2005) recommended having therapists adopt a strengths-based approach and being more active in sessions. They also stated therapists should explore support systems and the circumstances for having immigrated; they should have a holistic view of the problems, including the psychological, social, spiritual, and family dynamics (Al-Krenawi \& Graham, 2005).

Therapists also should remember that violence in Muslim marriages can range from emotional violence to physical violence (Ibrahim \& Abdalla, 2011). In addition to this, therapists should receive intensive training on evaluating intimate partner violence in order to recognize the signs; they should provide support and referral resources to victims (McPhail, Busch, Kulkarni, \& Rice, 2007). The feminist approach emphasizes the importance of empowerment and self-determination work for female victims of partner violence (McPhail, Busch, Kulkarni, \& Rice, 2007). Fulu and Miedima (2016) stated that, in the USA, women with high status have lower rates of violence. This knowledge illustrates that women with high status in the community can be a protective factor for Muslim women. In addition to high status, having less pressure towards divorce and having more balanced marriage roles can also be considered protective factors in Muslim marriages (Fulu \& Miedima, 2016). For this reason, contributing to the positive image of women and their education is fundamental in preventing and combatting partner violence. As previously cited, Muslim women might be confused about their duties and responsibilities and may be under the pressure of their roles. Isgandarova (2017) recommended that the Islamic community can be used for advising women not to view tolerating violence as a religious duty. Collaborating with Muslim community would also be compelling for encouraging Muslim women to seek help and support in violent situations.

While almost all societies oppose partner violence, facing this might manifest in different ways. According to Hajjar (2004), countries should be responsible for protecting citizens from family violence, for providing resources to combat violence in domestic settings, and for regulating laws. Khan (2006) stated that educating 
families about the effects of domestic violence and supporting training for religious leaders to increase awareness of violence in Muslim families should be the most important steps taken. Religious leaders can play an active role in preventing partner violence by giving speeches against partner violence and training the Muslim community (Cunradi, Caetano, \& Schafer, 2002). Finally, preventing and combatting partner violence requires interdisciplinary work.

\section{References}

Abugideiri, S. (2010). The peaceful families project: Addressing domestic violence in Muslim communities. Partner Abuse, 1(3), 363-76.

Al-Krenawi, A., Graham,J. (2005). Marital therapy for Arab Muslim Palestinian couples in the context of reacculturation. The Family Journal: Counseling and Therapy for Couples and Families, 13(3), 300-310. DOI: 10.1177/1066480704273640

Ammar, N., Couture-Carron, A., Alvi, S., San Antonio, J. (2014). Experiences of Muslim and nonMuslim battered immigrant women with the police in the United States: A Closer understanding of commonalities and differences. Violence Against Women, 19(12), 1449-71.

Ayyub, R. (2000). Domestic violence in the South Asian Muslim immigrant population in the United States. Journal of Social Distress and the Homeless, 9(3), 237-48.

Cunradi, CB., Caetano, R., Schafer, J. (2002). Religious affiliation, denominational homogamy, and intimate partner violence among US couples. Journal for the Scientific Study of Religion. 41(1), 139-151.

Daneshpour, M. (1998). Muslim families and family therapy. Journal of Marital and Family Therapy, 24(3), 355-67.

Daneshpour, M. (2016). Family therapy with Muslims. New York: Routledge.

Faizi, N. (2001). Domestic violence in the Muslim community. Texas Journal of Women and the Law, 10(2), 209-30.

Fulu, E., Miedema, S. (2016). Globalization and changing family relations: Family violence and women's resistance in Asian Muslim societies. Sex Roles, 74, 480-94.

Hajjar, L. (2004). Religion, state power, and domestic violence in Muslim societies: A framework for comparative analysis. Law \& Social Inquiry, 29(1), 1-38.

Ibrahim, N. \& Abdalla, M. (2010). A critical examination of Qur'an 4:34 and its relevance to intimate partner violence in Muslim families. Journal of Muslim Mental Health, 5, 327-49.

Intimate partner violence: definitions. (2018, 23 October). Retrived from https://www.cdc.gov/ violenceprevention/intimatepartnerviolence/definitions.html

Isgandarova, N. (2017). The role of Islam in preventing domestic violence towards Muslim women in Azerbaijan. Spiritual Psychology and Counseling, 2, 183-202. http://dx.doi.org/10.12738/ spc.2017.2.0019

Isgandarova, N. (2018). Muslim women, domestic violence, and psychotherapy theological and clinical issues. New York: Routledge.

Khan, F. (2006). A Muslim response to domestic violence. Journal of Religion \& Abuse, 8(1), 79-82. 
McPhail, B. A., Busch, N. B., Kulkarni, S., \& Rice, G. (2007). An integrative feminist model: The evolving feminist perspective on intimate partner violence. Violence Against Women, 13(8), 817-841.

Mohamad, M. (1996). Islam: the misunderstood religion. Jati, Bilangan 2, Disember 1996.

Robinson, R. (2010). Boundary battles: Muslim women and community identity in the aftermath of violence. Women's Studies International Forum, 33, 365-73. 